\title{
SIMULATION OF IRON CORROSION IN LEAD-MAGNESIUM EUTECTIC (LME) USING OXYGEN INHIBITOR
}

\author{
Umi Sa'adah $^{1}$, Artoto Arkundato ${ }^{1}$ and Moh. Hasan ${ }^{2}$ \\ ${ }^{1}$ Physics Department, Faculty of Mathematics and Natural Sciences - University of Jember \\ Jalan Kalimantan No. 37, Sumbersari, Jember, 68121 \\ ${ }^{2}$ Mathematics Department, Faculty of Mathematics and Natural Sciences - University of Jember \\ Jalan Kalimantan No. 37, Sumbersari, Jember, 68121 \\ E-mail:171820201003@students.unej.ac.id
}

\begin{abstract}
SIMULATION OF IRON CORROSION IN LEAD-MAGNESIUM EUTECTIC (LME) USING OXYGEN INHIBITOR. Lead-magnesium $(\mathrm{Pb}-\mathrm{Mg})$ is a metal that considered to have potential as a coolant raw material in the heat transfer system of nuclear reactors. However, the coolant in the form of Pb-Mg eutectic is corrosive to structured materials (eg steel cladding) used in reactors. In this research, steel material is represented by pure iron to simplify the simulation and calculation. This research aims to determine the effect of temperature on iron corrosion and the effect of adding oxygen as an inhibitor to reduce the iron corrosion rate in LME. In this study, corrosion was observed by looking at (coefficient) the diffusion of iron atoms into LME. A large iron diffusion coefficient represents high iron corrosion. To see inhibition effectivity with oxygen, the most effective oxygen concentration that can reduce the iron diffusion coefficient is searched. Simulations of iron corrosion and inhibition are performed using molecular dynamics simulation. The result of this research showed that oxygen concentration mixed into LME for effective inhibition of iron corrosion was in the range of $0.125 \mathrm{wt} \%-0.135 \mathrm{wt} \%$ (for temperatures of $973 \mathrm{~K}$ ). Thus, oxygen is believed that able to inhibit iron corrosion in $\mathrm{Pb}-\mathrm{Mg}$ eutectic up to $98.44 \%$
\end{abstract}

Keywords: Corrosion in liquid metals, Molecular dynamics, Lead-magnesium alloys, Oxygen concentration

\begin{abstract}
ABSTRAK
SIMULASI KOROSI BESI DALAM LOGAM CAIR TIMBAL-MAGNESIUM (LME) MENGGUNAKAN INHIBITOR OKSIGEN. Timbal-magnesium ( $\mathrm{Pb}-\mathrm{Mg})$ merupakan logam yang dianggap mempunyai potensi sebagai bahan baku coolant pada sistem transfer panas reaktor nuklir. Namun coolant dalam bentuk logam paduan $\mathrm{Pb}-\mathrm{Mg}$ cair ini bersifat korosif pada material berstruktur (misalnya baja cladding) yang digunakan dalam reaktor. Untuk menyederhanakan simulasi dan perhitungan pada penelitian ini maka material baja diwakili oleh besi murni. Penelitian ini bertujuan untuk mengetahui pengaruh temperatur pada korosi besi dan pengaruh pemberian oksigen sebagai inhibitor guna menekan laju korosi besi dalam $L M E$. Dalam penelitian ini korosi diamati dengan melihat (koefisien) difusi dari atom-atom besi ke dalam $L M E$. Koefisien difusi besi yang besar menggambarkan korosi besi yang tinggi. Untuk melihat efektivitas penghambatan dengan oksigen, dicari konsentrasi oksigen yang paling efektif untuk menurunkan koefisien difusi besi. Simulasi korosi besi dan penghambatannya dilakukan dengan simulasi dinamika molekul. Hasil penelitian menunjukkan bahwa konsentrasi oksigen yang dicampurkan ke dalam $L M E$ untuk penghambatan korosi besi yang efektif yaitu berada pada rentang $0,125 \mathrm{wt} \%-0,135 \mathrm{wt} \%$ (untuk temperatur $973 \mathrm{~K}$ ). Dengan demikian oksigen dipercaya mampu menghambat korosi besi dalam logam cair $\mathrm{Pb}-\mathrm{Mg}$ hingga 98,44\%.
\end{abstract}

Kata kunci: Korosi dalam logam cair, Dinamika molekul, Paduan timbal-magnesium, Konsentrasi oksigen 


\section{INTRODUCTION}

One of the important things when applying the liquid metal as a heat transfer medium in nuclear reactors is to maintain the corrosion of the used materials as steel cladding [1]. Liquid metal (coolant) such as lead and lead alloy had been studied since the beginning of the development of fast reactors [2]. The study mostly was focusing to reduce the corrosion of the cladding material due to the applied liquid metal as coolant. The cladding material is classified as a structural material that generally made of steel where iron is a major component (approximately $70 \%$ iron) [3].

The nuclear reactor needs a coolant system to sustain the operation. The most current popular coolant material for fast nuclear reactors is lead $(\mathrm{Pb})[4]$. $\mathrm{Pb}$ has a boiling point above the melting point of the cladding material and has a very low melting point [5]. $\mathrm{Pb}$ also has higher thermal conductivity compared to water [6]. Reactors that are designed using this coolant have several advantages: can be installed at atmospheric pressure, the coolant having very high boiling points outside the reactor temperature, this coolant does not react to water and air [7].

However, it is known that the cladding material experiences high corrosion when directly exposed to liquid $\mathrm{Pb}$ that usually at high temperatures. It is known that the solubility of steel components in liquid $\mathrm{Pb}$ at high temperatures is very high [6]. The high solubility of iron in liquid $\mathrm{Pb}$ produces iron corrosion [8]. Corrosion reduces the durability of reactor operation, and this important problem has posed a major challenge in the application of $\mathrm{Pb}$ for fast reactor design [9].

Arkundato et al. [10] have conducted an initial study of iron corrosion in the liquid lead along with mitigation to reduce the corrosion by using oxygen. In that study, the oxygen gas is sprayed into the liquid lead coolant with the variation of oxygen concentration and iron temperatures. From that study, they found that the sprayed oxygen concentration should be in the range of $0.0535 \mathrm{wt} \%-0.0895 \mathrm{wt} \%$ at the temperature of $1023 \mathrm{~K}$ for effective corrosion iron inhibition $(70 \%$ reduction corrosion).

Subsequent research has been developed by Alekseev [11], that is designing $\mathrm{Pb}-\mathrm{Mg}$ eutectic as coolant for example $\mathrm{Pb}_{0,83} \mathrm{Mg}_{0,17}$. This metal alloy has a melting point of $521 \mathrm{~K}$. This $\mathrm{Pb}-\mathrm{Mg}$ eutectic is believed to have the ability to inhibit corrosion at high temperatures. According to Orlova [12], Pb-Mg alloy has more potential to reduce corrosion in steel compared to pure $\mathrm{Pb} . \mathrm{Mg}$ has a melting point of $923 \mathrm{~K}$, although it is greater than $\mathrm{Pb}$ this value is still far below Fe which has a melting point of $1811 \mathrm{~K}$. In addition, $\mathrm{Mg}$ material has a higher thermal conductivity compared to $\mathrm{Pb}$, which is $160 \mathrm{Wm}^{-1} \mathrm{~K}^{-1}$ [5]. However, according to Lyon [7], $\mathrm{Pb}$ alloys are still significantly corrosive to construction materials (such as steel). This is caused by dissolved oxygen in the lead which reacts with the alloy material it contains. Therefore it is also necessary to control/ limit the amount of oxygen in it.

Based on the previous studies above, we want to conduct a simulation to develop knowledge about the corrosion of iron in $\mathrm{Pb}-\mathrm{Mg}$ eutectic and it's inhibition using oxygen. Based on Khairulin's experiments [13], temperature variations for lead-magnesium eutectic is in the range of $950 \mathrm{~K}-1000 \mathrm{~K}$. In this simulation, we will also investigate the relation of corrosion and different temperatures conditions.

The simulation study was conducted using the molecular dynamics method which is a method to simulate the movements of interacting atoms/molecules [14]. The simulation produces atoms trajectories that can be used to determine the diffusion coefficient of the atom [15].

According to Manly [8], corrosion in liquid metals is as caused by the high dissolution of steel atoms into liquid metal at high temperatures. This corrosion phenomenon is known as "hot corrosion" in which the mechanism of corrosion is observed from the physical process of steel atoms diffusion into liquid metal alloys. In the event of "hot corrosion", the diffusion process is considered more dominant than the chemical reaction process.

Based on Arkundato's research [16], to study the hot corrosion process, especially in the perspective of computer simulation, one of the conveniences in studying the corrosion phenomenon is seen based on the diffusion process. We can compute the material diffusion coefficient to observe the related corrosion. Arkundato et al had observed the iron corrosion and inhibition in the liquid lead. They used iron as a simplification of steel. They used oxygen to inhibit iron corrosion. Basically the smaller the diffusion coefficient value, the lower the level of corrosion.

Based on the experimental and theoretical backgrounds above [16], we want to develop knowledge about iron corrosion in $\mathrm{Pb}-\mathrm{Mg}$ eutectic and its inhibition using computational molecular dynamics method. This research aims to determine the performance of iron in hot $\mathrm{Pb}-\mathrm{Mg}$ eutectic. By knowing the performance of iron in lead-magnesium coolant in term of corrosion properties, it is hoped to be used as a basic reference for the design of nuclear reactors in the future.

\section{COMPUTER EXPERIMENT}

Research on iron corrosion in lead-magnesium eutectic was carried out using molecular dynamics computational methods. This method requires a number of simulation inputs such as modeling the structure of the material system, Lennard-Jones potential functions, input variables, and simulation procedures for calculating the diffusion coefficient values and the iron crystal structure. The software used in this research is MOLDY software and OVITO software. 


\section{Model of the Structure of Material}

Iron is modeled in the form of a cube (BCC Crystal structure) which is placed in the center of the $\mathrm{Pb}-\mathrm{Mg}$ eutectic (Figure 1).

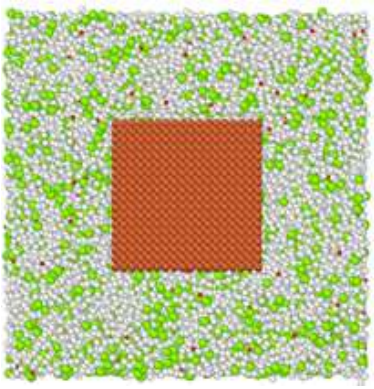

(a). Iron in $\mathrm{Pb}-\mathrm{Mg}$ eutectic

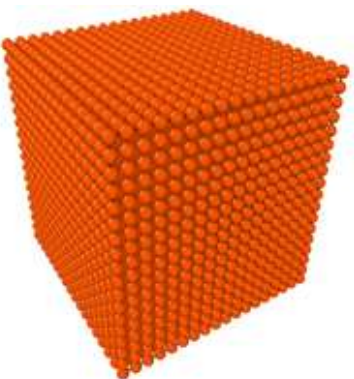

(b). Iron bcc crystal
Figure 1. $\mathrm{BCC}$ iron placed in the center of $\mathrm{Pb}-\mathrm{Mg}$ eutectic.

Figure 1a shows a visualization of iron in $\mathrm{Pb}-\mathrm{Mg}$ eutectic. Figure $1 b$ is a visualization of the initial iron crystal structure (BCC) before simulation. In figure $1 \mathrm{~b}$, it can be seen that the iron crystal structure is still perfect. The dimensions of the cube are $123 \times 123 \times 123$. The number of Fe atoms is 10745 . Whereas the liquid metal consists of 33769 (97.5 wt\%) Pb atoms and 6916 (2.5 $\mathrm{wt} \%) \mathrm{Mg}$ atoms. In this study, several variations were applied for temperature and oxygen concentration (which were injected into the liquid metal). Temperature varies: 973K, 1023K, 1073K, 1123K, 1173K, 1223K, 2223K, and $2273 \mathrm{~K}$. While variations in oxygen concentration are: 0 atoms, 340 atoms $(0.067 \mathrm{wt} \%), 450$ atoms $(0,09$ wt $\%), 674$ atoms $(0.135 \mathrm{wt} \%), 906$ atoms $(0.1798 \mathrm{wt} \%)$, 1132 atoms $(0.225 \mathrm{wt} \%)$, and 1348 atoms $(0.269 \mathrm{wt} \%)$.

\section{Method and Procedure}

The simulation procedure for diffusion coefficient calculation as following step:

(I) Creating the input file that contains: (1) information of material structure as Figure 1, (2) Lennard-Jones potential parameters [17] (see Table 1).

Table 1. Lennard - Jones potential parameters

\begin{tabular}{ccc}
\hline Pair interaction & $\sigma(\AA)$ & $\varepsilon(\mathrm{eV})$ \\
\hline $\mathrm{Fe}-\mathrm{Fe}$ & 0.4007 & 2.3193 \\
$\mathrm{~Pb}-\mathrm{Pb}$ & 0.1910 & 3.1888 \\
$\mathrm{Mg}-\mathrm{Mg}$ & 0.1292 & 2.9234 \\
$\mathrm{O}-\mathrm{O}$ & 0.0102 & 3.4280 \\
$\mathrm{Fe}-\mathrm{Pb}$ & 0.2766 & 2.7541 \\
$\mathrm{Fe}-\mathrm{Mg}$ & 0.2275 & 2.6214 \\
$\mathrm{~Pb}-\mathrm{Mg}$ & 0.1571 & 3.0561 \\
$\mathrm{Fe}-\mathrm{O}$ & 0.0639 & 2.8737 \\
$\mathrm{~Pb}-\mathrm{O}$ & 0.0441 & 3.3084 \\
$\mathrm{Mg}-\mathrm{O}$ & 0.0363 & 3.1757 \\
\hline
\end{tabular}

(II) Creating the input file of simulation control containing: temperature, simulation step, pressure, etc.
(III) Check Equilibration condition

In this research, the equilibration condition was achieved after 40000 of the integration step. The simulation was done for 100000 duration of integration steps (see Figure 2). It becomes a reference to continue the simulation and carry out physical calculations.

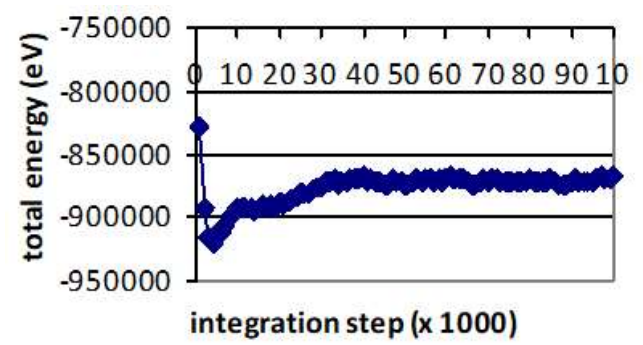

Figure 2. Equilibrium curve of a simulated energy system

(IV) Observation of iron corrosion and inhibition.

The simulation is divided into 2 steps: (1) simulation to see iron corrosion in lead-magnesium eutectic without oxygen inhibitors, (2) simulation to see the effect of giving oxygen and the effect of temperature on iron corrosion in lead-magnesium eutectic.

(V) Data analysis:

a. Calculation of iron diffusion coefficients

Diffusion calculation requires a calculation of Mean Square Displacement (MSD) which is part of the Einstein relation.

$$
M S D=\left\langle|\vec{R}(t)-\vec{R}(0)|^{2}\right\rangle
$$

MSD shows the average movement of atoms. MSD contains information about the atomic diffusion (position coordinates of the atom). Then MSD is used to calculate the diffusion coefficient $(D)$.

$$
D=\lim _{t \rightarrow \infty} M S D / 6 t
$$

For calculating the diffusion coefficient that temperature-dependent is using the Arrhenius equation [18].

$$
D(T)=D_{0} \cdot e^{\left(\frac{-A}{\Re T}\right)}
$$

b. Visualization of iron crystal structures.

After calculating the diffusion coefficient, the visualization of the crystal structure is done by using OVITO software [19].

\section{c. Calculation of iron corrosion reduction}

To find out the percentage of iron corrosion that can be reduced due to oxygen concentration is calculated using the equation

$$
\text { reduction }=\left|\frac{D_{\text {initial }}-D_{\text {thebest }}}{D_{\text {initial }}}\right| \times 100 \% \ldots \ldots
$$


where, reduction is decrease in corrosion rate (\%), $D_{\text {initial }}$ is iron diffusion coefficient before adding oxygen $\left(\mathrm{m}^{2} / \mathrm{s}\right)$, and $D_{\text {the best }}$ is iron diffusion coefficient after adding oxygen $\left(\mathrm{m}^{2} / \mathrm{s}\right)$.

\section{RESULTS AND DISCUSSIONS}

\section{Iron Corrosion in LME}

As explained in the research procedure that for the first stage of the simulation is to produce a picture of the structure of iron crystals where the iron is placed in the middle of lead-magnesium eutectic without oxygen inhibitors (Figure 3).

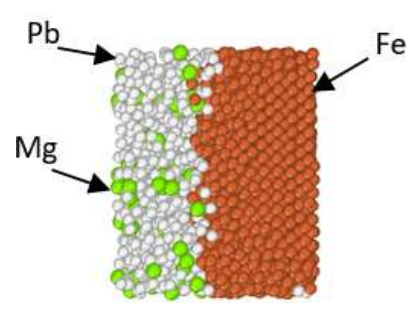

(a). In corrosion area

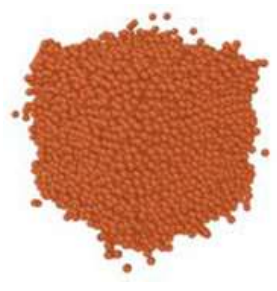

(b). In Pb-Mg eutectic
Figure 3. Visualization of iron corrosion in $\mathrm{Pb}-\mathrm{Mg}$ eutectic at temperature $973 \mathrm{~K}$ (without oxygen injection)

Figure 3a shows the interaction between liquid metal atoms (lead and magnesium) with iron. Lead and magnesium atoms can penetrate the surface of the iron, causing damage to the initial structure of the iron (corrosion). Figure $3 \mathrm{~b}$ is a complete visualization of iron in the eutectic $\mathrm{Pb}-\mathrm{Mg}$ where it shows that the iron structure has dissolved (no longer in the form of BCC). The dissolution event of the iron crystal structure due to $\mathrm{Pb}-\mathrm{Mg}$ eutectic was studied using the diffusion coefficient. To find out the calculation details of the diffusion coefficient, we need an $\ln D$ and $1 / T$ curve (Figure 4).

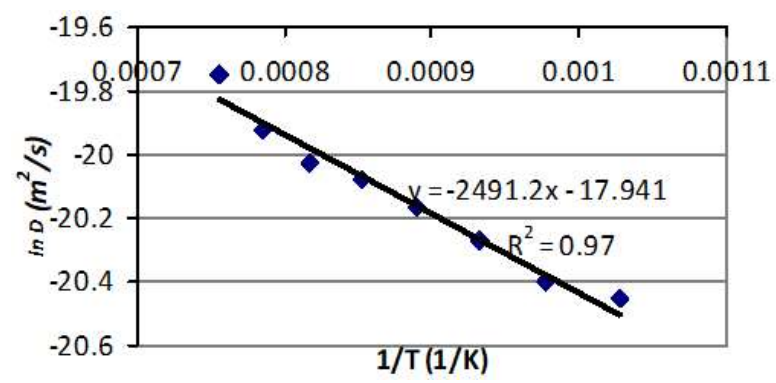

Figure 4. Plot of $\ln (\mathrm{D})$ and $1 / \mathrm{T}$ from simulations of iron in $\mathrm{Pb}-\mathrm{Mg}$ eutectic

The data in Figure 4 was obtained from simulations of iron corrosion in eutectic $\mathrm{Pb}-\mathrm{Mg}$ before adding an oxygen inhibitor. Simulations are carried out at various temperatures $(973 \mathrm{~K}, 1023 \mathrm{~K}, 1073 \mathrm{~K}, 1123 \mathrm{~K}$, $1173 \mathrm{~K}, 1223 \mathrm{~K}, 2223 \mathrm{~K}, 2273 \mathrm{~K})$. From the simulation results, the relationship between $1 / T$ and $\ln D$ is obtained so that the graph in figure 4. Then the data obtained is used to determine linear approximation with the gradient in the figure 4 . The $\mathrm{x}$-axis shows the value of $1 / T$ and the $\mathrm{y}$-axis shows the value of $\ln D$. The gradient of the linear curve in Figure 4 produces mathematical equations as follows:

$$
\ln D=-2491.2\left(\frac{1}{T}\right)-17.941
$$

From equation 5 we get a formula to determine the iron diffusion coefficient in equation 6.

$$
D(T)=1.615 \times 10^{-8} \cdot e^{\left(-2491.2 \times \frac{1}{T}\right)}\left(\mathrm{m}^{2} / \mathrm{s}\right) \ldots \ldots
$$

From equation 6 we can plot the graph to explain the temperature influence of iron diffusion coefficient as shown in Figure 5.

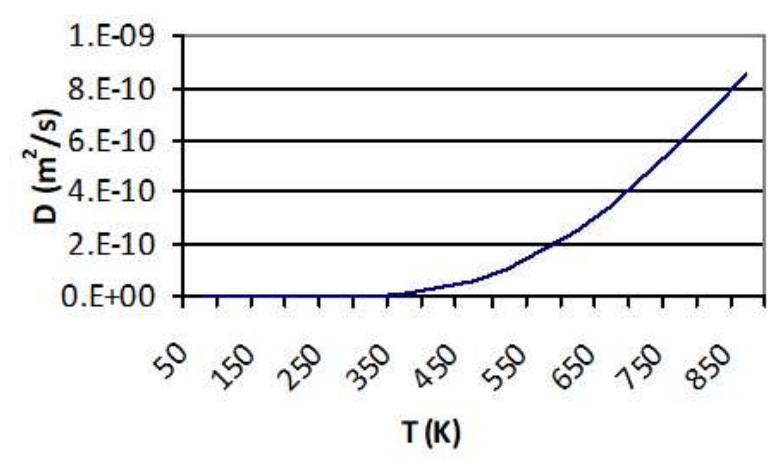

Figure 5. Plot of $\mathrm{D}(\mathrm{T})$ and $\mathrm{T}$ for $\mathrm{FePbMg}$ simulation.

It can be seen that temperature influences the iron diffusion coefficient value. The higher temperature, the greater iron diffusion coefficient.

\section{Effect of Oxygen Injection as a Corrosion Inhibitor}

The second simulation produces a picture of the iron crystals structure in which iron is placed in the center of lead-magnesium eutectic after being added an oxygen inhibitor (Figure 6a and 6b). Figure 6a shows that oxygen goes to the iron surface to form an oxide layer to protect the iron from lead and magnesium atoms. But there are a few oxygen atoms that able to penetrate

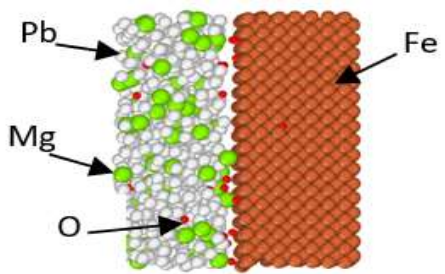

(a). In corrosion area

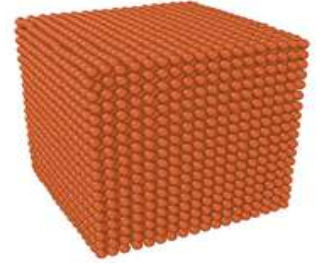

(b). In $\mathrm{Pb}-\mathrm{Mg}$ eutectic $(0,135 \mathrm{wt} \%$ oxygen $)$
Figure 6. Visualization of iron corrosion in $\mathrm{Pb}-\mathrm{Mg}$ eutectic at temperature $973 \mathrm{~K}$ (with $0.135 \mathrm{wt} \%$ oxygen). 
iron has shown in figure 6a. This such conditions may change the iron structure. Therefore should be a limit to the amount of effective oxygen concentration to be added in the $\mathrm{Pb}-\mathrm{Mg}$ eutectic.

Figure $6 \mathrm{~b}$ is a visualization of the structure of iron crystals in $\mathrm{Pb}-\mathrm{Mg}$ eutectic which is added oxygen with a concentration of $0.135 \mathrm{wt} \%$. When compared to figure $3 \mathrm{~b}$ it is clear that there has been a reduction in iron corrosion due to the addition of oxygen to the eutectic $\mathrm{Pb}-\mathrm{Mg}$. This is evidenced by the similarity between figure $6 b$ and figure $1 b$.

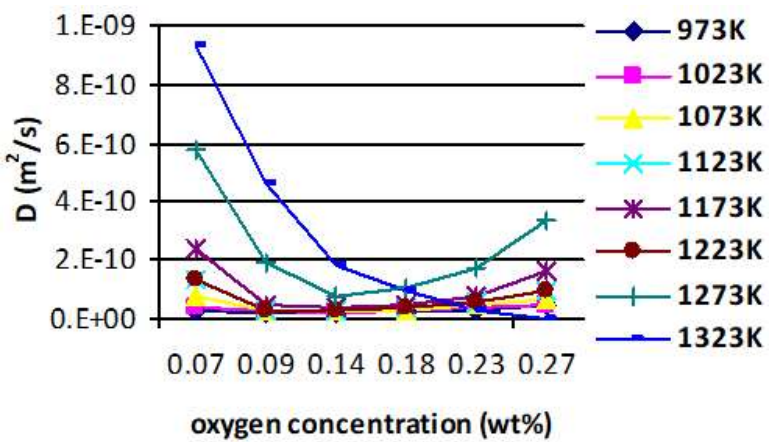

Figure 7. Graph of diffusion coefficient of iron for variations concentration of Oxygen.

Figure 7 shows the effect of applying variations of oxygen concentration as an iron corrosion inhibitor in the $\mathrm{Pb}-\mathrm{Mg}$ eutectic. At temperatures, $973 \mathrm{~K}-1273 \mathrm{~K}$ illustrates the same diffusion coefficient trend. However, for $1273 \mathrm{~K}$ the diffusion coefficient graph has a rather far range compared to the diffusion coefficient graph for the temperature of $973 \mathrm{~K}-1223 \mathrm{~K}$. The lowest value of the iron diffusion coefficient in the $\mathrm{Pb}-\mathrm{Mg}$ eutectic is when added oxygen with a concentration of $0.135 \mathrm{wt} \%$. It shows that oxygen has the ability to inhibit corrosion optimally in that concentration.

At a temperature $1323 \mathrm{~K}$ has a different trend graph where the greater the concentration of oxygen supplied, the lower the iron corrosion. Overall (for all temperature variations), the diffusion coefficient was highest when given an oxygen concentration of $0.067 \mathrm{wt} \%$. While at a concentration of $0.09 \mathrm{wt} \%$ the diffusion coefficient values at various temperatures began to decrease. Then the values of diffusion coefficient began to rose when the concentration of oxygen is above $0.1798 \mathrm{wt} \%$.

In lead alloy systems, oxygen is very influential in the environment due to the high level of contamination [2]. In this research, iron is solid, lead and magnesium metals are liquid, and oxygen is gas. Based on the four materials, oxygen is the lightest and most energetic. So that oxygen will fill the cavity between solid iron and $\mathrm{Pb}-\mathrm{Mg}$ eutectic. Oxygen dissolves into lead alloys to the surface of the steel to form a protective layer through the diffusion process [4]. The dissolved oxygen must be concentrated within a certain range to be effective as a protective layer. The upper limit of oxygen is used to avoid contamination by the cooling oxides. While the lower limit of oxygen is used to increase corrosion protection by the self-healing oxide layer [2]. In this research, the most effective limitation of oxygen concentration to inhibit iron corrosion in $\mathrm{Pb}-\mathrm{Mg}$ eutectic is about $0.125 \mathrm{wt} \%$ to $0.135 \mathrm{wt} \%$. In that range, the most optimal amount of oxygen concentration in inhibiting corrosion is $0.135 \mathrm{wt} \%$ at temperature $973 \mathrm{~K}-1273 \mathrm{~K}$. By using equation 4 , it can be calculated the percentage of iron corrosion reduction. The values of the diffusion coefficient before adding oxygen inhibitor can be seen from figure 5 while its value of diffusion coefficient after added oxygen can be seen from figure 7 (look at the optimum oxygen concentration or low diffusion value). And the results can be seen in Table 2.

Table 2. Reduction of iron corrosion

\begin{tabular}{cccc}
\hline $\begin{array}{c}\text { Temperature } \\
(\mathrm{K})\end{array}$ & $\begin{array}{c}\mathrm{D}_{\text {initial }} \\
\left(\mathrm{m}^{2} / \mathrm{s}\right)\end{array}$ & $\begin{array}{c}\mathrm{D}_{\text {the best }} \\
\left(\mathrm{m}^{2} / \mathrm{s}\right)\end{array}$ & $\begin{array}{c}\text { Reduction } \\
(\%)\end{array}$ \\
\hline 973 & $1.25 \mathrm{E}-09$ & $1.95 \mathrm{E}-11$ & 98.44 \\
1023 & $1.41 \mathrm{E}-09$ & $2.29 \mathrm{E}-11$ & 98.38 \\
1073 & $1.58 \mathrm{E}-09$ & $2.59 \mathrm{E}-11$ & 98.37 \\
1123 & $1.76 \mathrm{E}-09$ & $3.05 \mathrm{E}-11$ & 98.26 \\
1173 & $1.93 \mathrm{E}-09$ & $3.66 \mathrm{E}-11$ & 98.11 \\
1223 & $2.11 \mathrm{E}-09$ & $3.05 \mathrm{E}-11$ & 98.55 \\
1273 & $2.28 \mathrm{E}-09$ & $7.57 \mathrm{E}-11$ & 96.68 \\
1323 & $2.46 \mathrm{E}-09$ & $1.81 \mathrm{E}-10$ & 92.65 \\
\hline
\end{tabular}

Table 2 shows that oxygen can inhibit iron corrosion optimally at temperatures of $973 \mathrm{~K}-1223 \mathrm{~K}$ with reduction above $98 \%$.

\section{CONCLUSIONS}

Research conducted using the molecular dynamics method has shown theoretical results and analysis of iron corrosion caused by eutectic $\mathrm{Pb}-\mathrm{Mg}$. Oxygen gas seems to be effective in inhibiting corrosion. The following conclusions are obtained:

1. Iron in lead-magnesium eutectic showed relatively high corrosion phenomenon.

2. With the oxygen addition into the lead-magnesium eutectic as an inhibitor for range concentration of $0.125 \mathrm{wt} \%-0.135 \mathrm{wt} \%$ (at temperature $973 \mathrm{~K}$ ), then this can reduce iron corrosion up to $98.44 \%$.

3. From the simulation, the mechanism of corrosion inhibition look likes that caused many oxygen atoms developing a barrier wall between liquid metal alloy and iron.

\section{ACKNOWLEDGMENTS}

The authors would like to thank Dr. Lutfi Rohman and Dr. Agus Suprianto who have given positive critics and suggestions of the paper, and also the computational physics lab., the University of Jember for providing the research facilities. 


\section{REFERENCES}

[1] J. Zhang, P. Hosemann, and S. Maloy, "Models of liquid metal corrosion," J. Nucl. Mater, vol. 404, no. 1,pp. 82-96, 2010.

[2] OECD/NEA, Handbook on Lead-bismuth Eutectic Alloy and Lead Properties, Materials Compatibility, Thermal-hydraulics and Technologies ORGANISATION FOR ECONOMIC CO-OPERATIONAND DEVELOPMENT, no. 6195. 2007.

[3] D.- Bodansky, Nuclear Energi, 'Principles, Practices, and Prospects, 2nd edition,' vol. 39, no. 5. 2004.

[4] J. Zhang and N. Li, "Review of the studies on fundamental issues in LBE corrosion," vol. 373, pp. 351-377, 2008.

[5] P. Parsons and G. Dissons, "The Periodic Table: $A$ field guide to the elements. " 2014.

[6] A. Z. Kashezhev, V. A. Sozaev, A. I. Khasanov, and A. G. Mozgovoi, “An Experimental Investigation of the Wetting of Reactor Steels," vol. 48, no. 5, pp. 793-795, 2010.

[7] S. Lyon, "Corrosion of Lead and its Alloys," no. December 2010, 2018.

[8] W. D. Manly, "Fundamentals of Liquid Metal Corrosion." 1956.

[9] A. Khalid and M. Takahashi, "Corrosion characteristics of materials in $\mathrm{Pb}-\mathrm{Bi}$ under transient temperature conditions,", J. Nucl. Mater., vol. 398, no. 1-3, pp. 139-145, 2010.

[10] A. Arkundato, Z. Su'Ud, M. Abdullah, W. Sutrisno, and M. Celino, "Inhibition of iron corrosion in high temperature stagnant liquid lead: A molecular dynamics study," Ann. Nucl. Energy, vol. 62,pp. 298-306, 2013.
[11] P. Alekseev and A. L. Shimkevich, "Eutectic Na$\mathrm{Tl}$ and $\mathrm{Pb}-\mathrm{Mg}$ alloys as liquid-metal coolants for fast nuclear reactors," no. April 2019, 2015.

[12] E. A. Orlova et al., "Self-organizing carbon nitride coatings on steel from molten lead - magnesium eutectic," Nucl. Energy Technol., vol. 1, no. 3, pp. 226-231, 2016.

[13] R. A. Khairulin, A. S. Kosheleva, and S. V Stankus, " Thermal Properties of Liquid Alloys of Magnesium-Lead System,"” vol. 14, no. 1, pp. 7580, 2007.

[14] K. Refson, “Moldy User 's Manual," 2001.

[15] J. M. Haile, I. Johnston, A. J. Mallinckrodt, and S. Mckay, "Molecular Dynamics Simulation: Elementary Methods," vol. 625, no. 1993, pp. 6-7, 1996.

[16] A. Arkundato, Z. Su'ud, Sudarko, M. Hasan, "Molecular dynamics simulation of corrosion mitigation of iron in lead-bismuth eutectic using nitrogen as corrosion inhibitor Molecular dynamics simulation of corrosion mitigation of iron in lead-bismuth eutectic using nitrogen as corrosion inhibitor," Phys. Conf. Ser. 622012009 , 2015.

[17] J. Davies, "“Calculation of the Lennard- Jones $n$ rn Potential Energy Paramcters for Metals, " vol. $595,1983$.

[18] A. Y. Kupryazhkin, A. N. Zhiganov, and D. V Risovany, "Simulation of diffusion of oxygen and uranium in uranium dioxide nanocrystals," vol. 372, no. 1, pp. 233-238, 2008.

[19] A. Stukowski, "Visualization and analysis of atomistic simulation data with OVITO - the Open Visualization Tool," vol. 015012, 2010. 